\title{
OBITUARIES
}

\section{Edward John (Ed) Immelman}

Ed Immelman's (1938 - 2013) education and professional training were marked by success and awards. Matriculating from Rondebosch Boys High School at 16, he studied medicine at the University of Cape Town, where he was awarded scholarships and a class medal for the best student in the third and fourth years, passing his final $\mathrm{MB} \mathrm{ChB}$ degree with honours and distinctions. Choosing surgery as his career, he trained at Groote Schuur Hospital, achieving his South African Surgical Fellowship examination in 1966, and the Fellowship of the Royal College of Surgeons of England in 1968.

His over-riding interest in vascular surgery can be traced to his attachment as Senior Registrar at the Bristol Royal Infirmary (1967 - 1970), in the dedicated Vascular Unit of Professor Joseph Peacock. With the super-specialisation of general surgical firms at Groote Schuur Hospital, he was to establish a dedicated Vascular Unit in 1982, one of the first in the country. He was also the major influence in the founding and running of the Peripheral Vascular Disease Clinic, and the Vascular Research Laboratory. He was a Founder Member, Executive Committee Member, and Past President of the Vascular Society of South Africa. He was appointed an Associate Professor in 1976, full Professor (second Chair of Surgery) in 1981, and Emeritus Professor on his retirement in 2000 .

He was an admired undergraduate teacher, and his style was to engage students in a jocular, challenging manner, making his tutorials a popular part of the curriculum. He received the Distinguished Teachers Award in 1989, the highest accolade given to teaching staff at all levels within the University. He was voted 'Teacher of the Year' by the final-year medical classes of 1997, 1998 and 1999.

One of his greatest strengths was training young surgeons in vascular surgery. Vascular research work was annually presented at the Surgical Research Society, the younger presenting the work with their mentor in the background. This research evolved into many publications in medical journals. It is no coincidence that most of the trainees who passed through his unit were to specialise in vascular surgery subsequently in their practices. He also supervised various BSc, MMed, MSc and ChM theses.

He had a lifelong interest in mineralogy, developing a valuable collection of many thousands of specimens, his particular focus being on classic mineral sites in southern Africa, with a major interest in the Tsumeb deposits in Namibia, his being the biggest such collection in the world. He leaves his wife Pat (McKenzie) whom he married in 1967, and his two sons, Robert, a general practitioner in Britain, and Grant, who is an engineering entrepreneur in the Cape, 5 grandchildren, and 3 great-grandchildren.

\section{David M Dent \\ Delawir Kahn \\ University of Cape Town}

\section{John Emile Cosnett}

Professor John Cosnett (1925 - 2012) began his medical career as a student at the University of the Witwatersrand. His registrar training in medicine was at the University of Natal; he then moved to Edendale Hospital in Pietermaritzburg as head of the medicine department, a position he held very successfully there for some 20 years, providing a high level of service and valuable guidance and training for aspiring physicians. John then decided to concentrate on his major interest - clinical neurology - and he moved to this department in Durban, where he was appointed as Associate Professor of Neurology and where he worked until his retirement in 1990. During these years, he published numerous articles on diverse medical topics (including the maladies of various characters in the works of Charles Dickens) and completed his MD dissertation on neurological disease in the Zulu people.

John was a most astute physician with a quiet, patient approach and exceptional ability to concentrate on the problem at hand and reach a conclusion in the most efficient manner. Many young doctors were inspired by his acumen, knowledge and wisdom, and the way he applied them in the clinical situation. He was known too for the dry humour that he introduced not infrequently, but never inappropriately, into his conversation.

After retirement, John and his charming wife Wendy gave up their pleasant Victorian home in Durban, moving to Northern Ireland to live near to their medical practitioner son and his family. The memory and influence of John Cosnett as an arch-physician, role model and friend will long remain.

\section{J Pudifin}

Department of Medicine, University of KwaZulu-Natal, Durban 